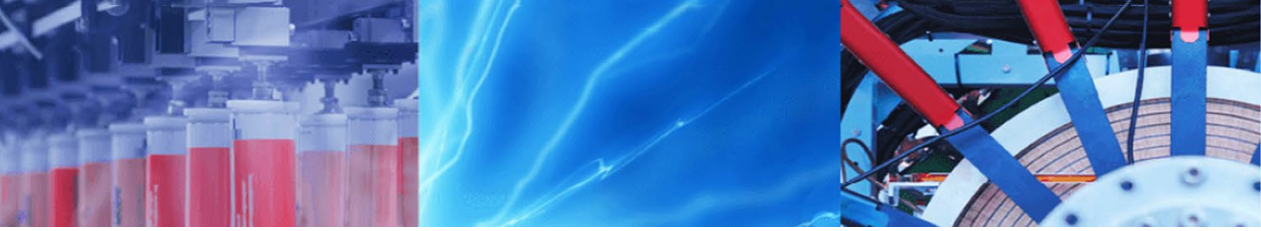

Research Article

\title{
Design improvement and experimental study on shell and tube condenser for bio-oil recovery from fast pyrolysis of wheat straw biomass
}

\author{
B. L. Salvi ${ }^{1}$ (I) $\cdot$ T. Soni $^{1} \cdot$ S. Jindal ${ }^{1} \cdot$ N. L. Panwar ${ }^{2}$
}

Received: 8 July 2020 / Accepted: 6 January 2021 / Published online: 22 January 2021

(c) The Author(s) 2021 OPEN

\begin{abstract}
In this study, the design improvement was done in a shell and tube condenser for improved heat transfer and condensation of bio-oil vapour. The developed condenser has split shell and segmental baffles, which divide the shell in various zones and condensate collection points. The fast pyrolysis of wheat straw was done and the bio-oil vapour condensate collected from various outlets located at bottom of condenser shell. From experimental results it was found that production of bio-oil increased from 10.2 to $20.8 \%$ with increase in cooling water flow rate from 1000 to $2500 \mathrm{~L} / \mathrm{h}$; but, further increasing it beyond $2500 \mathrm{~L} / \mathrm{h}$ provide marginal effects on production of bio-oil. The production of bio-oil increased from 15.2 to $20.7 \%$ as sweep gas flow rate was increased from 20 to $40 \mathrm{~L} / \mathrm{min}$ at $2500 \mathrm{~L} / \mathrm{h}$ of cooling water flow rate. But, further increase in sweep gas flow rate beyond $40 \mathrm{~L} / \mathrm{min}$ resulted in to decrease in production of bio-oil. The novelty of this work is development of improved condenser with segmental baffles, which help in fractional condensation of bio-oil vapour, split shell for cleaning of outer surface of the cooling water tubes and compact design of condenser for optimal condensation of bio-oil.
\end{abstract}

Keywords Fast pyrolysis · Bio-oil · Shell and tube condenser · Segmental baffle · Split shell

\section{Introduction}

Search for alternative sources of energy is the need of time due to increasing consumption and requirement of energy. The massive use of fossil fuels for energy production and thermal applications are causing to environmental pollution. The rapid consumption and depletion of fossil fuel reserves are increasing the concern towards protection of environment. Therefore, there is need for development into sustainable sources of energy. The bioenergy is one of the vital sources of renewable energies. Wood and other forms of biomass are some of the main sources of renewable liquid, gaseous and solid fuels [1]. Biomass is renewable in nature and extensively considered to be prospective renewable source of energy for the future. The biomass is transformed into fuel and energy through biomass conversion technology (i.e., torifection, pyrolisys and gasification), which provide solid, liquid and gaseous fuels. These biofuels can become potential fuel for themal heating or electricity generation application $[2,3]$. After pyrolysis of biomass, the bio-oil decomposes from the feedstock and come out in the form of bio-oil vapour.

The hypothesis is that sweep gas flow rate affect the releasing and transportation of bio-oil from reactor to the condensing media. Further, the biomass pyrolysis is generating the bio-oil vapour, which has to be condensed for effective recovery of the bio-oil. With continuous operation of pyrolysis unit, due to tar deposition on the surface

B. L. Salvi, salvibl@yahoo.in | ${ }^{1}$ Department of Mechanical Engineering, College of Technology and Engineering, Maharana Pratap University of Agriculture and Technology, Udaipur, Rajasthan 313001, India. ${ }^{2}$ Department of Renewable Energy Engineering, College of Technology and Engineering, Maharana Pratap University of Agriculture and Technology, Udaipur 313001, Rajasthan, India. 
of cooling water tubes the effective heat transfer through condenser decreases. Now, how to improve the heat transfer through condenser and increase the production of biooil? For this the literature review was carried out for biooil production and design of condensers. The objectieves followed by methodology, and reseulsts and discussion are presented.

\section{Bio-oil production}

The liquid fuel obtained through biomass pyrolysis is termed as 'bio-oil'. The bio-oil is a dark brown and freeflowing organic liquid. It is used in co-firing of boilers, furnace, diesel-engine, etc. The bio-oil is also known by other names such as pyrolysis oils, pyrolysis liquids, bio-crude oil, wood oil, wood distillates, wood liquids, etc. The biooil is produced by thermal degradation of biomass, called pyrolysis. It leads to the formation of bio-char, bio-oil and non-condensable gases [4]. The process may be slow, fast or flash pyrolysis, depending upon the operating conditions during the pyrolysis.

Generally, fast pyrolysis process is used for better production of bio-oil as compared to flash pyrolysis, but it has some technological limitations such as poor thermal stability [5]. Along with fast pyrolysis, the fluidized bed technology appears to be the most potential technology in fast pyrolysis of biomass for bio-oil as it offers a high heating rate, rapid devolatization, easy control, convenient char collection, low cost and so on. In pyrolysis process the wood decomposition begins at $200^{\circ} \mathrm{C}$ and reaches to maximum rate of mass loss at $350^{\circ} \mathrm{C}$, and continued to $500{ }^{\circ} \mathrm{C}$ [6]. The decomposed wood convert into bio-oil vapour, ash, tar, etc. The bio-oil vapour comes out from the reactor at temperature of about $180-250^{\circ} \mathrm{C}$, then passes through the char separator and then enters into the condenser in the temperature range of about $100-120^{\circ} \mathrm{C}$.

The production of bio-oil depends upon the type of feedstock and operating conditions of pyrolysis process. Jendoubi et al. [7] studied fast pyrolysis process of wheat straw and used jacketed tubular condensers for fractional production of bio-oil. The production of bio-oil from fast pyrolysis of grape bagasse was $27.60 \%$ [8]. The auger pyrolysis process of pine wood obtains the production of bio-oil of about $25.7 \%$ by using three condensers in series with water cooling circulation [9]. The highest yield of biooil from sugarcane trash was $31.95 \%$ for $\mathrm{N}_{2}$ as sweep gas at the flow rate of $160 \mathrm{cc.s} \mathrm{s}^{-1}$ [10]. Arias et al. [11] reported that pyrolytic conversion of perennial grass and woody shurbs at $550^{\circ} \mathrm{C}$ with $\mathrm{N}_{2}$ as sweep gas yields about $18 \%$ bio-oil and there is need to upgrade the aqueous fractions in pyrolysis liquids. In pyrolysis process, apart from the operating conditions, the sweep gas flow rate, cooling fluid flow rate and proper design of condenser play major role in production of bio-oil.

\subsection{Condenser for bio-oil production}

The selection of condenser, i.e., type and size of condenser, is based upon suitability for a process depending on the type of fluid, its phase, temperature range, pressure and various other thermodynamics properties [12]. The bio-oil is slightly corrosive in nature and tar is generated during its formation. Over the period during its operation the tar deposits over condenser wall and tubes, and leads to decrease in the recovery of bio-oil over the period. Bio-oil is acidic in nature and reacts with materials. The mild steel is least resistant to corrosion, while stainless steel is not affected under any condition [13, 14]. Various condensing system including direct condensation systems and indirect cooling system (i.e., shell and tube heat exchangers), e.g., Graham condenser, Coil condenser, Allihn condenser and Spiral condenser, for bio-oil production were reviewed by [15]. They reported the need for fractional condensation by using multi-stage condenser for improved quality of bio-oil. The geometrical parameters of the shell and coil type condenser desing have a significant effect on effective heat trahnsfer [16].

The fractional condensation was achieved by multistage condensers, i.e., three condensers in series and different grades of bio-oils were obtained [17]. Conversely, to improve the recovery of bio-oil, the condenser should work for longer period with better condensation and reduced tar deposition on the outer surface of cooling water tubes for compact system and reduced overall cost. Wang et al. [18] worked on fractional condensation to obtain different grades of bio-oil by using separate condesers for each fraction of condensate. Gooty et al. [19] studied on fractionated using a series of three condensers maintained at different temperatures. Ma et al. [20] worked on fixed-bed biomass pyrolysis reactor integrated with three-stage condensation columns. They studied the effects of pyrolysis temperature, carrier gas flow rate and condensation temperature on bio-oil yield and reported the maximum yield at $550{ }^{\circ} \mathrm{C}$. In most of the studies the fractional condensation was achieved by using multistage condensation units, which require more space and intial capital cost as well as more running cost. No boby is reporting about long term operation of the condensers and the maintenance aspects.

The present work is aimed for design improvement and development of compact condenser with baffle plates for fractional condensation, and splited shell for tar cleaning and enhancement in bio-oil recovery from fast pyrolysis of wheat straw biomass. The detailed experimental study on effect of variation in cooling 
Table 1 Properties for 304 stainless steel alloys [21]

\begin{tabular}{ll}
\hline Property & Value \\
\hline Density & $8.00 \mathrm{~g} / \mathrm{cm}^{3}$ \\
Melting point & $1450^{\circ} \mathrm{C}$ \\
Modulus of elasticity & $193 \mathrm{GPa}$ \\
Tensile strength & $500-700 \mathrm{MPa}$ \\
Electrical resistivity & $0.72 \times 10^{-6} \Omega . \mathrm{m}$ \\
Thermal conductivity & $16.2 \mathrm{~W} / \mathrm{m} . \mathrm{K}$ \\
Corrosion resistance & Excellent corrosion resistance \\
Resistance to oxidation & Good resistance to oxidation \\
& in intermittent service up to \\
& $870^{\circ} \mathrm{C}$ \\
\hline
\end{tabular}

water flow rate and sweep gas flow rate on vapour temperature and production of bio-oil yield is carried out.

\section{Materials and methods}

\subsection{Design of shell and tube condenser for bio-oil vapour}

In the present study a shell and tube type counter flow condenser is selected to condense the hot bio-oil vapour. A counter flow type shell and tube condenser consists of shell and tube or series of tubes, where cooling water is circulated through tubes and hot bio-oil vapour is circulated in the shell around water tubes. Some portion of the condensed bio-oil vapour leads to tar formation and deposition around the surface of tubes, which are to be cleaned. Therefore, split shell was used for opening of the shell in order to clean the outer surface of cooling water tubes. The bio-oil is acidic in nature, so condenser shell and tube material selected should be inert to the bio-oil vapour. Therefore, the 'Stainless Steel 304' was selected as material for shell and tube. The properties of stainless stell 304 are shown in Table 1.

The general formula for heat transfer across surface of condenser is given by Eq. (1).

$Q=U A_{s} \Delta T_{m}$ where, $Q=$ Heat transfer per unit time, $W ; U=$ Overall heat transfer coefficient, $\mathrm{W} / \mathrm{m}^{2}{ }^{\circ} \mathrm{C} ; \mathrm{A}_{\mathrm{s}}=$ Heat transfer area, $\mathrm{m}^{2} ; \Delta T_{m}=$ The mean temperature difference across heat exchanger structure, ${ }^{\circ} \mathrm{C}$. The parameters such as diameter of shell, diameter of tube, tube layout, length of tube, etc. are calculated by using the logarithmic mean temperature difference method (LMTD) method [12]. By conservation of energy for condenser system and assuming outlet gas temperature as $50^{\circ} \mathrm{C}$, the outlet cooling water temperature is calculated by using Eq. (2).

$Q=\dot{m}_{h} C_{p h}\left(t_{h 1}-t_{h 2}\right)=\dot{m}_{c} C_{p c}\left(t_{c 2}-t_{c 1}\right)$

where, $\dot{m}_{h}$ and $=\dot{m}_{c}$ mass flow rate of hot fluid and cold fluid, $\mathrm{kg} / \mathrm{s}, \mathrm{C}_{\mathrm{ph}}$ and $\mathrm{C}_{\mathrm{pc}}=$ specific heat of hot fluid and cold fluid, $\mathrm{kJ} / \mathrm{kg}$. All temperature values are in degree centigrade $\left({ }^{\circ} \mathrm{C}\right), t_{h_{1}}$ and $t_{h_{2}}=$ temperature of hot fluid (vapour) in and hot fluid (gases) out, $t_{c_{1}}$ and $t_{c_{2}}=$ temperature of cold fluid (water) in and cold fluid (water) out.

Now the "logarithmic mean temperature difference" (LMTD or $\theta_{m}$ ) method is used to find the length and other parameters such as surface area of cooling water tubes, etc. The LMTD is calculated by Eq. (3).

$\theta_{m}=\frac{\left(t_{h_{1}}-t_{c_{2}}\right)-\left(t_{h_{2}-} t_{c_{1}}\right)}{\log \frac{t_{h_{1}}-t_{c_{2}}}{t_{h_{2}-} t_{c_{1}}}}=\frac{\theta_{2}-\theta_{1}}{\log \frac{\theta_{2}}{\theta_{1}}}$

Now, by using Eq. (1), the required heat transfer surface area of condenser tube is calculated by Eq. (4),

$A_{s}=\frac{\mathrm{Q}}{\mathrm{U} \theta_{m}}$

Since, the length of condenser shell is restricted and the cooling water tube diameter is selected from the manufacturer catalogue. Then, the surface area of one tube having length equivalent to condenser length is calculated by Eq. (5).

$\mathrm{A}_{t}=\pi d L$

where, $d=$ diameter of tube, $L=$ length of tube as length of condenser shell.

Now, the number of required cooling water tubes, ' $n$ ' is given by Eq. (6)

$n=\frac{\text { Total surface area required for single tube of selected diameter }}{\text { Surface area of single tube equivalent to length of condenser shell }}=\frac{A_{s}}{A_{t}}$ 
In order to improve heat transfer and maximum recovery of bio-oil, the segmental baffles are placed in a shell and tube condenser to guide the vapour flow direction. This helps in longer duration of vapour flow and better cooling. Height of baffle was selected three-fourth of shell diameter [22].

For designing the compact condenser with fractional condensation of bio-oil vapour, initially the length of condenser shell was taken as $1000 \mathrm{~mm}$ and shell diameter $168 \mathrm{~mm}$. The other parameters taken were sweep gas flow rate $\dot{m}_{h}=0.0007 \mathrm{~kg} / \mathrm{s}$, cooling water flow rate $\dot{m}_{c}=$ $0.6 \mathrm{~kg} / \mathrm{s}, C_{\mathrm{ph}}=1.5 \mathrm{~kJ} / \mathrm{kgK}$, inlet vapour temperature $t_{h_{1}}=$ $110{ }^{\circ} \mathrm{C}$ (temperature of outlet vapour from the pyrolysis reactor), outlet gas temperature $t_{h_{2}}=50^{\circ} \mathrm{C}$ (as desired outlet gas temperature), and cooling water temperature $t_{c_{1}}=$ $27^{\circ} \mathrm{C}$. Using Eqs. (1), (2), (3), (4), (5) and (6), the calculations

Table 2 Specifications of the condenser

\begin{tabular}{lll}
\hline S.No & Parameter & Dimension \\
\hline 1 & Length of condenser shell & $1000 \mathrm{~mm}$ \\
2 & Shell inner diameter, $\mathrm{D}_{\mathrm{s}}$ & $150 \mathrm{~mm}$ \\
3 & Shell outer diameter, $\mathrm{D}_{\mathrm{o}}$ & $168 \mathrm{~mm}$ \\
4 & Shell thickness & $3.40 \mathrm{~mm}$ \\
5 & Tube outer diameter, $\mathrm{d}_{\mathrm{o}}$ & $32 \mathrm{~mm}$ \\
6 & Number of tubes, $\mathrm{N}_{\mathrm{t}}$ & 5 \\
7 & Baffle cut & $55 \%$ \\
9 & Baffle thickness, $\mathrm{t}$ & $5.0 \mathrm{~mm}$ \\
10 & Number of baffle plates, $\mathrm{N}_{\mathrm{b}}$ & 6 \\
\hline
\end{tabular}

were done and specifications of the designed condenser are given in Table 2.

\subsection{Development of heat exchanger}

The counter flow shell and tube heat exchanger was developed by using the design specifications as shown in Table 2. The shell and tube condenser consist of two inlets and two outlets for vapour and cooling water. The other three outlets provided in the shell are for extraction of the produced bio-oil. The shell consists of six segmental baffles and five tubes. The baffles are provided at equal distances which divide the shell in various zones. The space between vapour inlet and second baffle is termed as Zone-1. The space between second and fourth baffle is called Zone-2, and space between fourth and sixth baffle is called Zone-3. Thermocouples at different locations were provided to observe the temperature of vapour in various zones of shell. The pressure gauge was provided to know the pressure difference in condenser shell. The split shell has provision to open at the top and sides as it was assembled with nut and bolt, which provides advantages of periodic cleaning of shell and tubes. Figure 1 shows the geometric model and parts of developed condenser.

\subsection{Experimental set up for pyrolysis}

The experimental set up of continuous fluidized bed type pyrolysis unit for feed rate of $5 \mathrm{~kg} / \mathrm{h}$, is shown in Fig. 2 . The experimental setup consists of hoper for feeding of sized biomass into the fluidized bed reactor, sweep gas
Fig. 1 Geometric model and parts of condenser

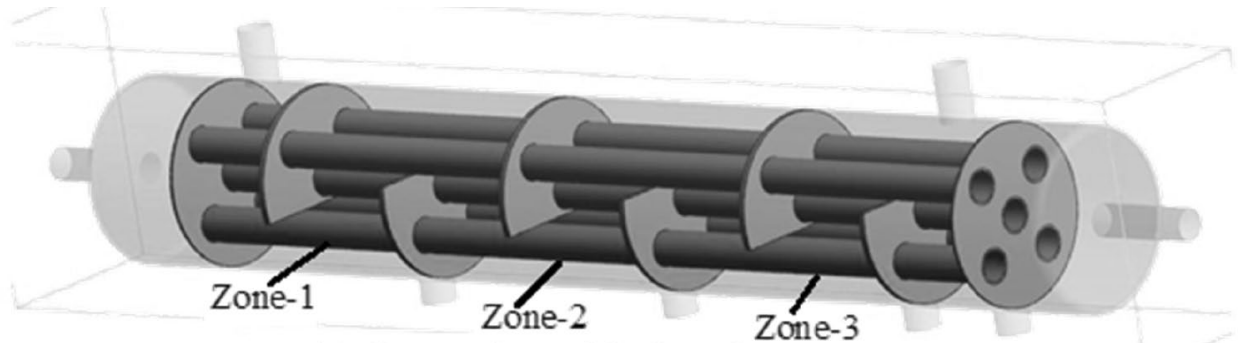

(a) Geometric model of condenser.

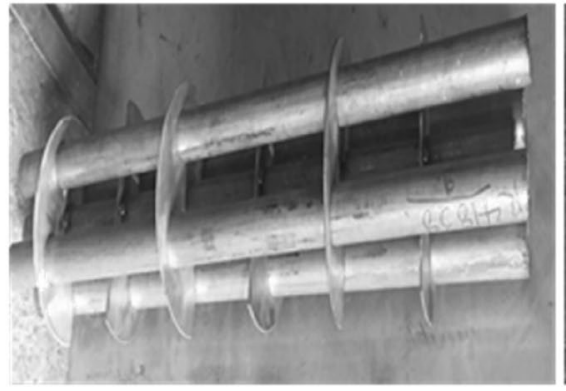

(b) Baffle and tube assembly.

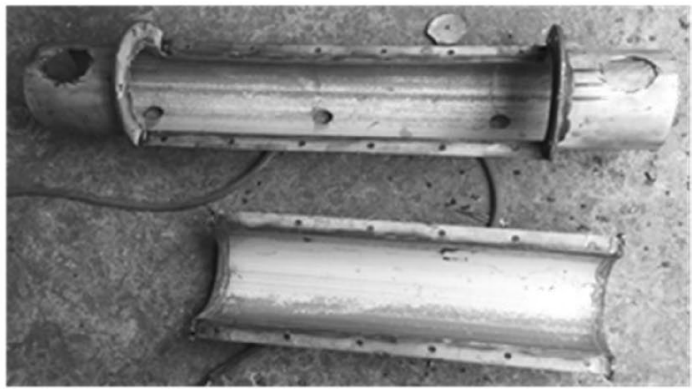

(c) Opened shell.

SN Applied Sciences 
Fig. 2 Experimental set up

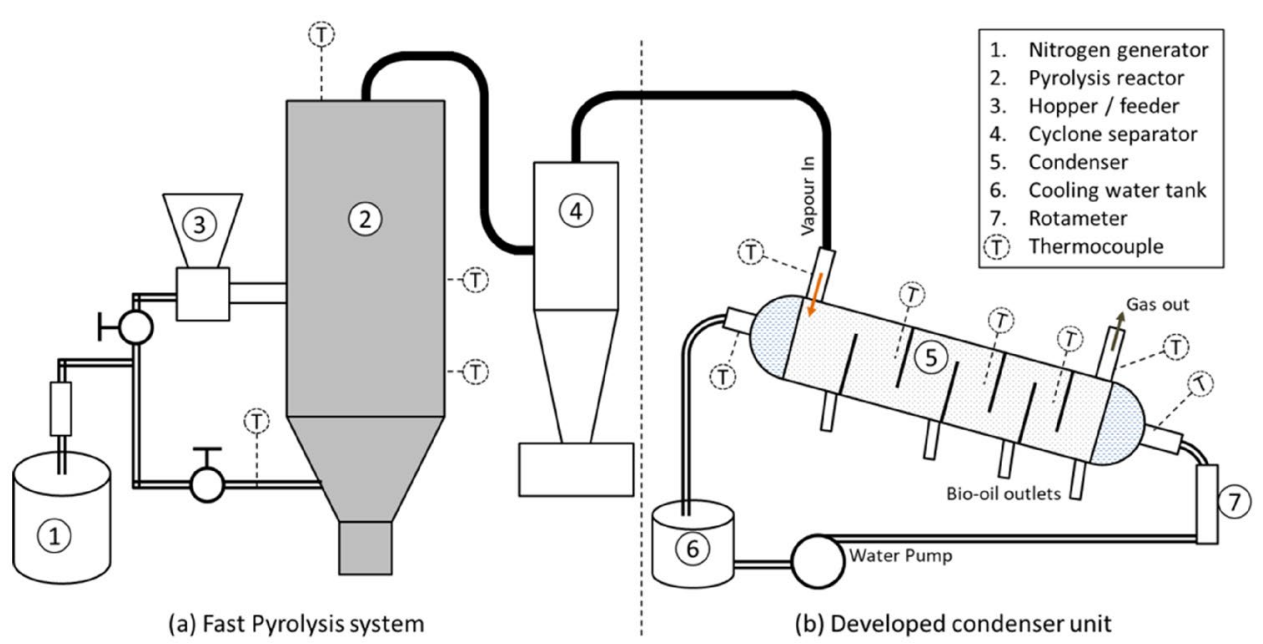

(a) Fast Pyrolysis system

(b) Developed condenser unit

generation and supply unit, cyclone separator, and condenser. The resistive heating element was used for heating the biomass for pyrolysis the temperature range of $350-550^{\circ} \mathrm{C}$. The nitrogen gas from nitrogen generator was used as sweep gas to carry forward the produced vapour. The set up was provided with cyclone separator, which separates the char and carry forward the clean hot bio-oil vapour. The hot bio-oil vapour produced from pyrolysis was used as feed for vapour condenser. The feedstock, naturally dried wheat straw with particle sizes between 1.0 and $15 \mathrm{~mm}$ and moisture content of $6-9 \%$ wt., was used as feedstock for pyrolysis reactor.

The shell and tube type counter flow condenser was used to condense the hot bio-oil vapour into liquid oil. The bio-oil vapour was passed through shell and cooling water at atmospheric temperature $27^{\circ} \mathrm{C}$, was circulated through tubes. The bio-oil vapour enters in the condenser in the temperature range of $100-110^{\circ} \mathrm{C}$. The parametric study was carried out by varying cooling water and sweep gas flow rates. The cooling water flow rate was varied in the range from 1000 to $3000 \mathrm{~L} / \mathrm{h}$ and the sweep gas flow rate was varied from 20 to $60 \mathrm{~L} / \mathrm{min}$. The flow rate was regulated by control valve and observed in Rotameter. The temperature variations were observed by $\mathrm{K}$ and J-type thermocouples attached at the inlet and outlet section of vapour and cooling water, and various zones of the condenser shell. The temperature at various zones in the condenser was also observed and recorded. The experimental set up of pyrolysis and condenser unit is shown in Fig. 2 .

Produced bio-oil was collected from the condensate collection points provided in the condenser. The production of bio-oil was measured on mass basis by using electronic weighing balance and wt. per cent bio-oil was calculated by using Eq. (7).
Bio- oil production $=\frac{\text { Mass of the bio }- \text { oil collected }}{\text { Total } \text { mass of feedstock consumed }} \times 100 \%$

\section{Results and discussion}

The condenser was designed and developed for condensation of hot bio-oil vapour. Then, experimental study was carried out on shell and tube condenser to evaluate the performance parameters. The study investigates the effect of varying cooling water flow rate and sweep gas flow rate on temperature of hot bio-oil vapour and production of bio-oil from wheat straw. The results are presented with $3 \%$ error in measurement.

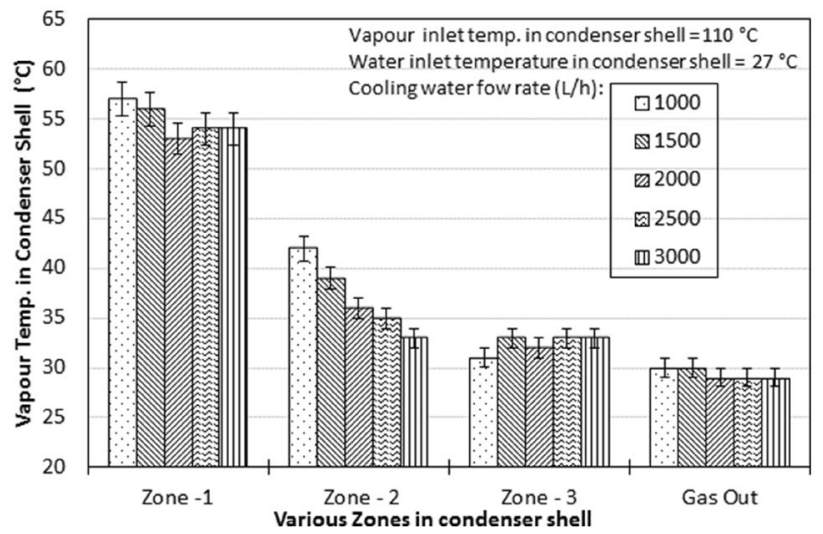

Fig. 3 Effect of variation in cooling water flow rate on zone temperature in condenser shell 


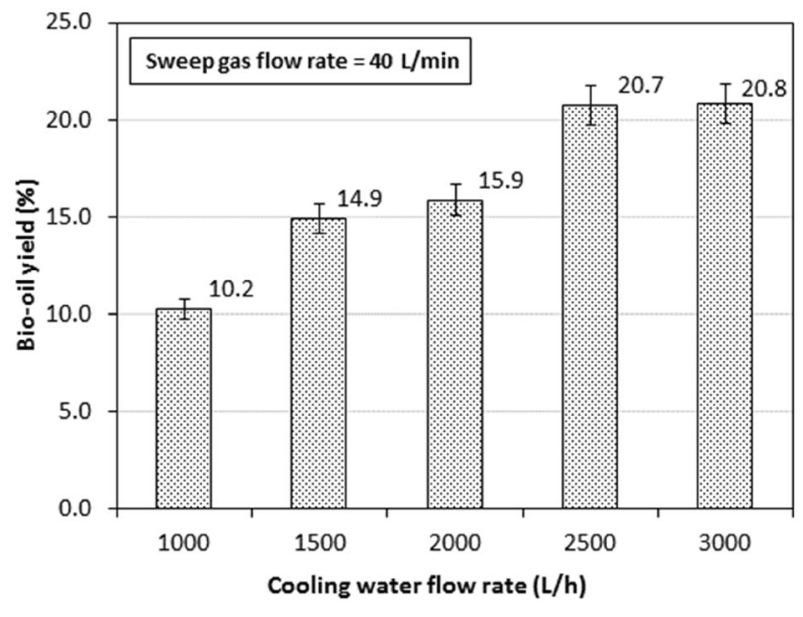

Fig. 4 Effect of cooling water flow rate on production of bio-oil

\subsection{Effects of cooling water flow rate on vapour temperature and production of bio-oil}

The effects of varying cooling water flow rate on vapour temperature in various zones of condenser are shown in Fig. 3. It can be observed from the Fig. 3 that temperature at various zones of condenser decreased with respect to increase in cooling water flow rate from 1000 to $3000 \mathrm{~L} / \mathrm{h}$. The maximum drop in vapour temperature was observed at initial zones i.e., Zone-1 to Zone-2, but in subsequent zones, i.e., Zone- 3 and gas out temperature drop was less significant and within error limits. With respect to increase in cooling water flow rate the vapour temperature decreased significantly in Zone-1 and Zone-2, but in later zones marginal effects were observed. At gas outlet, the temperature is similar at all flow rates, as sufficient cooling is being done.

The effects of varying cooling water flow rate on bio-oil production are shown in Fig. 4. The production the bio-oil increased from 10.2 to $20.8 \%$ with respect to increase in cooling water flow rate from 1000 to $3000 \mathrm{~L} / \mathrm{h}$. It can be observed from the Fig. 4 that by increasing cooling water flow rate up to $2500 \mathrm{~L} / \mathrm{h}$, the bio-oil production increased; but further increase in cooling water flow rate had marginal effects on production of bio-oil. Therefore, excess use of water flow rate is not useful. It reflects that most of the condensable contens would have condensed at cooling water flow rate $2500 \mathrm{~L} / \mathrm{h}$. The optimum production of bio-oil was found to be $20.7 \%$ at the cooling water flow rate of $2500 \mathrm{~L} / \mathrm{h}$ and sweep gas flow rate $40 \mathrm{~L} / \mathrm{min}$.

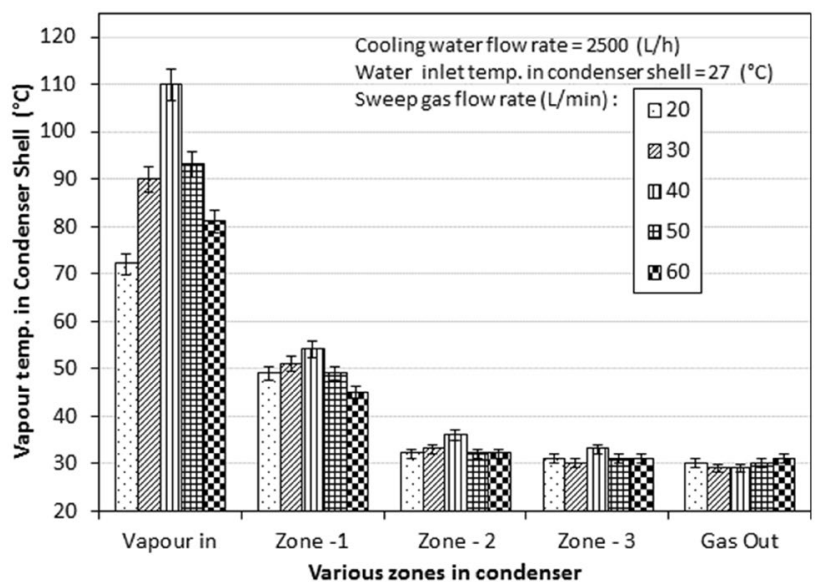

Fig. 5 Effect of sweep gas flow rate on zone temperature of condenser

\subsection{Effects of sweep gas flow rate on vapour temperature}

The effects of varying sweep gas flow rate on zone temperature of condenser are shown in Fig. 5 . It can be observed from Fig. 5 that vapour temperature at vapour in section of the condenser varied with respect to change in sweep gas flow rate. Initially vapour temperature increase, reached to maximum $110^{\circ} \mathrm{C}$ at sweep gas flow rate of $40 \mathrm{~L} / \mathrm{min}$ and then further increase in sweep gas flow rate caused to decrease in vapour temperature at condenser inlet. The low temperature at low flow rate of sweep gas may be due to cooling of vapour in the vapour travelling path and less sweeping of bio-oil vapour from the pyrolysis reactor. At comparatively higher sweep gas flow rate, again the vapour temperature at vapour inlet decreased. This may be due to less heating at very fast flow rate of sweep gas.

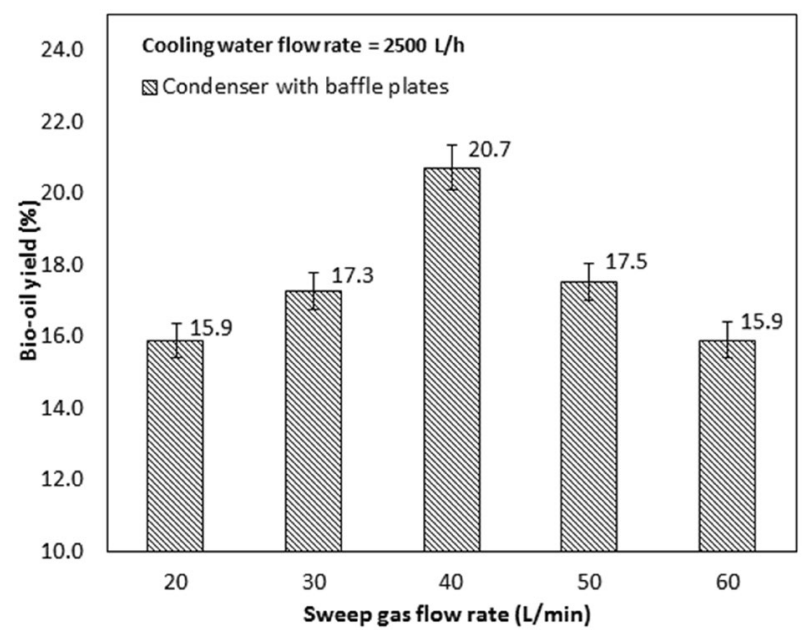

Fig. 6 Effect of sweep gas flow rate on production of bio-oil 
In subsequent zones, the vapour temperature decreased continually and at gas outlet, the gas temperature was almost constant with in error limit irrespective of any flow rate of sweep gas.

\subsection{Effects of sweep gas flow rate on production of bio-oil}

The effects of varying sweep gas flow rate on production of bio-oil are shown in Fig. 6. It is observed from the Fig. 6 that production of bio-oil increased from 15.9 to $20.7 \%$ with respect to increase in sweep gas flow rate from 20 to $40 \mathrm{~L} / \mathrm{min}$ at cooling water flow rate of $2500 \mathrm{~L} / \mathrm{h}$. But, further increment in sweep gas flow rate from 40 to $60 \mathrm{~L} / \mathrm{min}$, the production of bio-oil decreased from 20.7 to $15.9 \%$. At low flow rate of sweep gas the bio-oil vapour would not be transported due to slow speed, while comparatively higher rate of sweep gas flow would not be allowing sufficient time for heating the biomass for releasing of the bio-oil. Therefore, maximum bio-oil production of $20.7 \%$ was observed at sweep gas flow rate of $40 \mathrm{~L} / \mathrm{min}$ and cooling water flow of $2500 \mathrm{~L} / \mathrm{h}$.

The bio-oil yield of $20.7 \%$ from wheat straw by using modified condenser is slightly lower than that of reported in literature $[8,10]$, but they have used different feedstocks. Furthermore, researchers have used multi-shell and tube condenser to increase the bio-oil production and fractional condensation [7]; while the presently designed and developed condenser is compact and single shell and tubes with baffle plates is providing enhanced production of bio-oil yield with fractional condensation. Various baffle plates and bio-oil outlet points can help in fractional condensation of bio-oil where different grade of bio-oil can be obtained. The results are in concerance with the results repoted by Jendoubi et al. [7] for pyrolysis of wheat straw where muti-satge condensation was done.

The sweep gas flow rate had significant effect on biooil recovery. At very low as well as at very high flow rate of sweep gas the bio-oil recovery was low. At lower flow rate of sweep gas the bio-oil would not be carried away from pyrolysis reactor, while the higher flow rate of sweep gas would be leading to less time for heating of biomass and subsequent releasing of bio-oil. Therefore, the hypothesis is true that sweep gas flow rate affect the production of bio-oil vapour from reacto.

In the entire study it was observed that along with type of biomass used, the cooling water flow rate and sweep gas flow rate significantly affect the production of bio-oil. The overall heat transfer coefficient calculated is $17.6 \mathrm{~W} /$ $\mathrm{m}^{2}{ }^{\circ} \mathrm{C}$. Long term operation of condenser is affected by deposition of tar inside condenser shell and outside of the cooling water tubes. Split condenser shell with open able window helps in cleaning of the condenser. The produced bio-oil can directly be used for thermal application in industrial burners and process heating. This condenser uses single shell and multi-tubes with baffle plates, which eliminates the multi-shells and overall cost of condenser is reduced.

\section{Conclusions}

The sweep gas flow rate affect the releasing and transportation of bio-oil vapour from reactor to the condensing media, while type and design of condenser affect the condensation of bio-oil vapour. A shell and tube counter flow condenser with split shell and baffle plates was designed and developed. The experimental study was carried out for optimal condensation of bio-oil vapour coming out from fast pyrolysis of wheat straw. It was found from the experimental results that production of bio-oil increased from 10.2 to $20.7 \%$ as cooling water flow rate was increased from 1000 to $2500 \mathrm{~L} / \mathrm{h}$, but further increase in cooling water flow rate marginally affected the bio-oil recovery. The production of bio-oil increased from 15.2 to $20.7 \%$ as sweep gas flow rate was increased from 20 to $40 \mathrm{~L} / \mathrm{min}$ at $2500 \mathrm{~L} / \mathrm{h}$ of cooling water flow rate. But, further increase in sweep gas flow rate beyond $40 \mathrm{~L} / \mathrm{min}$ resulted in to decrease in production of bio-oil. For certain sweep gas flow rate of $40 \mathrm{~L} / \mathrm{min}$ and the cooling water flow rate of $2500 \mathrm{~L} / \mathrm{h}$, the maximum bio-oil recovery of $20.7 \%$ was observed for wheat straw. Comparatively low flow rate of sweep gas could not transfer the bio-oil vapour from reactor and it would be converted into syngas, while high flow rate of sweep gas do not allow sufficient heating of the biomass to decompose into bio-oil vapour.

The significant outcome of this study is development of compact condenser with segmental baffles, which divided the condenser shell in various zones, where fractional condensation of bio-oil could be achieved with multi-point oil extraction. The split shell helps in periodically cleaning of shell and outer surface of cooling water tubes in order to maintain better heat transfer and condensation of bio-oil. Further, characterization of fractioned condensate may be done while developing bio-fuel. The experimental results for gas temperature along the up stream length of condenser shell may be used for numerical modeling of the condenser and developing the empirical relations for design of condenser.

Acknowledgement This work was supported by the Indian Council of Agricultural Research (ICAR), New Delhi for Coordinated Research Platform on 'Energy from Agriculture'. 


\section{Compliance with ethical standards}

Conflict of interest On behalf of all authors, the corresponding author states that there is no conflict of interest.

Open Access This article is licensed under a Creative Commons Attribution 4.0 International License, which permits use, sharing, adaptation, distribution and reproduction in any medium or format, as long as you give appropriate credit to the original author(s) and the source, provide a link to the Creative Commons licence, and indicate if changes were made. The images or other third party material in this article are included in the article's Creative Commons licence, unless indicated otherwise in a credit line to the material. If material is not included in the article's Creative Commons licence and your intended use is not permitted by statutory regulation or exceeds the permitted use, you will need to obtain permission directly from the copyright holder. To view a copy of this licence, visit http://creativecommons .org/licenses/by/4.0/.

\section{References}

1. Bridgwater AV, Peacocke GVC (2000) Fast pyrolysis processes for biomass. Renew Sust Energ Rev 4:1-74

2. Panwar NL, Salvi BL, Reddy VS (2011) Performance evaluation of producer gas burner for industrial application. Biomass Bioenergy 35(3):1373-1377. https://doi.org/10.1016/j.biomb ioe.2010.12.046

3. Prasad L, Salvi BL, Kumar V (2015) Thermal degradation and gasification characteristics of Tung shells as an open top downdraft wood gasifier feedstock. Clean Technol Environ Policy 17(6):1699-1706. https://doi.org/10.1007/s10098-014-0891-8

4. Ji-lu Z (2007) Bio-oil from fast pyrolysis of rice husk: yields and related properties and improvement of the pyrolysis system. $J$ Anal Appl Pyrolysis 80:30-35

5. Cornelissen T, Yperman Y, Reggers GS, Carleer R (2008) Flash copyrolysis of biomass with polylactic acid. Part 1: influence on bio-oil yield and heating value. Fuel Proc Technol 87:1031-1041

6. Mohan D, Pittman CU Jr, Steele PH (2006) Pyrolysis of wood/ biomass for bio-oil: a critical review. Energy Fuels 20:848-889

7. Jendoubi N, Broust F, Commandre JM, Mauviel G, Sardin M, Lede $J(2011)$ Inorganic distribution in bio-oil and char produced by biomass fast pyrolysis: the key role of aerosols. J Anal Appl Pyrolysis 92:59-67

8. Demirbas A (2011) Competitive liquid biofuels from biomass. Appl Energy 88:17-28

9. Kim P, Weaver S, Labbe N (2016) Effect of sweeping gas flow rates on temperature- controlled multistage condensation of pyrolysis vapour in an auger intermediate pyrolysis system. J Anal Appl Pyrolysis 118:325-334
10. Treedet W, Suntivarakorn R (2011) Sugarcane trash Pyrolysis for bio-oil production in a fluidized bed reactor. Bioenergy Technology, World Renewable Energy Congress 2011 - Sweden, 8-13 May 2011, Linkoping, Sweden, pp 140-147

11. Arias ER, Bertero $M$, Jozami E, Feldman SR, Falco $M$, Sedran U (2020) Pyrolytic conversion of perennial grasses and woody shrubs to energy and chemicals. SN Appl Sci 2:116. https://doi. org/10.1007/s42452-019-1911-4

12. Cengel YA (2007) Heat and Mass Transfer (a practical approach). Mc Graw-Hill Public, New Delhi

13. Darmstadt H, Garcia-Perez M, Adnot A, Chaala A, Kretschmer D, Roy C (2004) Corrosion of metals by bio-oil obtained by vacuum pyrolysis of softwood bark residues. An X-ray photoelectron spectroscopy and auger electron spectroscopy study. Energy Fuels 18(5):1291-1301. https://doi.org/10.1021/ef0340920

14. Lu Q, Zhang J, Zhu X (2008) Corrosion properties of bio-oil and its emulsions with diesel. Chin Sci Bull 53:3726. https://doi. org/10.1007/s11434-008-0499-7

15. Papari S, Hawboldt K (2018) A review on condensing system for biomass pyrolysis process. Fuel Process Technol 180:1-13

16. Zaboli M, Ajarostaghi SSM, Noorbakhsh M, Delavar MA (2019) Effects of geometrical and operational parameters on heat transfer and fluid flow of three various water based nanofluids in a shell and coil tube heat exchanger. SN Appl Sci 1:1387. https ://doi.org/10.1007/s42452-019-1431-2

17. Johansson A, lisa $K$, Sandström $L$, Ben $H$, Pilath $H$, Deutch $S$, Wiinikka H, Öhrmana OGW (2017) Fractional condensation of pyrolysis vapors produced from Nordic feeds tocks in cyclone pyrolysis. J Anal Appl Pyrol 123:244-254

18. Wang C, Ding H, Zhang Y, Zhu X (2020) Analysis of property variation and stability on the aging of bio-oil from fractional condensation. Renew Energy 148:720-728. https://doi. org/10.1016/j.renene.2019.10.159

19. Gooty AT (2014) Dongbing Li, cedric briens, franco berruti, fractional condensation of bio-oil vapors produced from birch bark pyrolysis. Sep PurifTechnol 124:81-88. https://doi.org/10.1016/j. seppur.2014.01.003

20. Ma S, Zhang L, Zhu L, Zhu X (2018) Preparation of multipurpose bio-oil from rice husk by pyrolysis and fractional condensation. J Anal Appl Pyrol 131:113-119. https://doi.org/10.1016/j. jaap.2018.02.017

21. https://www.azom.com/article.aspx?ArticlelD=2867, (Accessed on 19-11-2020)

22. Kumar DS (2013) Heat and mass transfer. S. K. Kataria \& Sons, New Delhi

Publisher's Note Springer Nature remains neutral with regard to jurisdictional claims in published maps and institutional affiliations. 